\title{
Activin and Inhibin in the Human Adrenal Gland Regulation and Differential Effects in Fetal and Adult Cells
}

Susan J. Spencer, Jaron Rabinovici, Sam Mesiano, Paul C. Goldsmith, and Robert B. Jaffe

Reproductive Endocrinology Center, Department of Obstetrics, Gynecology and Reproductive Sciences, University of California, San Francisco, California 94143

\begin{abstract}
Recent experimental data have revealed that activins and inhibins exert pivotal effects on development. As part of our studies on growth and differentiation of the human fetal adrenal gland, we examined the subunit localization, as well as the mitogenic and steroidogenic actions of activin and inhibin in human fetal and adult adrenals. All three activin and inhibin subunit proteins $(\alpha, \beta \mathrm{A}$, and $\beta \mathrm{B})$ were detected in the fetal and adult adrenal cortex. Immunoreactive activin-A dimer was demonstrated in midgestation fetal and neonatal adrenals. $\mathbf{A C T H}_{1-24}$-stimulated fetal adrenal cell expression of $\alpha$ and $\beta A$ subunit messenger RNA. In addition, ACTH elicited a rise in levels of immunoreactive $\alpha$ subunit secreted by fetal and adult adrenal cells. Human recombinant activin-A inhibited mitogenesis and enhanced ACTH-stimulated cortisol secretion by cultured fetal zone cells, but not definitive zone or adult adrenal cells. Recombinant inhibin-A had no apparent mitogenic or steroidogenic effects. Thus, activin selectively suppressed fetal zone proliferation and enhanced the ACTH-induced shift in the cortisol/dehydroepiandrosterone sulfate ratio of fetal zone steroid production. These data indicate that activin- $\mathrm{A}$ may be an autocrine or paracrine factor regulated by $\mathrm{ACTH}$, involved in modulating growth and differentiated function of the human fetal adrenal gland. (J. Clin. Invest. 1992. 90:142-149.) Key words: adrenal development $\cdot$ differentiation $\bullet$ inhibin $\bullet$ cortisol
\end{abstract}

\section{Introduction}

Activin is a homodimeric glycoprotein structurally related to inhibin and other members of the transforming growth factorbeta (TGF- $\beta)^{1}$ superfamily of developmentally significant peptides (1). Although activin was originally isolated from the gonad and characterized because of its ability to stimulate pituitary follicle-stimulating hormone (FSH) production (2), it is becoming apparent that it has many key biologic functions. It

Presented in part at the 36th Annual Meeting of the Society for Gynecological Investigation, San Antonio, TX, 20-23 March 1991.

Address correspondence and reprint requests to Robert B. Jaffe, M.D., Reproductive Endocrinology Center, Department of Obstetrics, Gynecology and Reproductive Sciences, University of California, San Francisco, CA 94142-0132.

Received for publication 21 May 1991 and in revised form 23 January 1992.

1. Abbreviations used in this paper: DHAS, dehydroepiandrosterone sulfate; EGF, epidermal growth factor; hpg, hypogonadal mouse; rhactivin-A, recombinant human activin-A; rh-inhibin-A; recombinant human inhibin-A; TGF- $\beta$, transforming growth factor beta.

J. Clin. Invest.

(c) The American Society for Clinical Investigation, Inc.

0021-9738/92/07/0142/08 \$2.00

Volume 90, July 1992, 142-149 is strongly conserved across species and may subserve different functions in the organism at different stages of development. Activin induces mesodermal formation in Xenopus (3), stimulates hematopoiesis in a variety of species (4-6), and can modulate the production of several pituitary trophic hormones (79 ), in addition to modulating growth and hormonal production in the pituitary-gonadal axis (2). Activins are $\beta-\beta$ dimers $\left(\beta_{\mathrm{A}}-\beta_{\mathrm{A}}\right.$ or activin-A; $\beta \mathrm{A}-\beta \mathrm{B}$ or activin-AB), whereas inhibins are $\alpha-\beta$ heterodimers $\left(\alpha-\beta_{\mathrm{A}}\right.$ or inhibin-A; $\alpha-\beta_{\mathrm{B}}$ or inhibin-B). The subunits of activin and inhibin are expressed in the adrenal gland of the rat (10) and of the fetal and adult sheep (11), but information on their expression or actions in the human adrenal gland is lacking.

The human fetal adrenal gland consists of two histologically and functionally distinct zones. The outer definitive zone is regarded as the principal forerunner of the adult cortex and secretes mainly cortisol (12). The inner fetal zone is unique to intrauterine life and comprises more than $80 \%$ of the fetal gland. The fetal zone grows rapidly in midgestation and produces large quantities of dehydroepiandrosterone sulfate (DHAS), a substrate for placental estrogen synthesis $(12,13)$. Despite numerous studies on the development of the human fetal adrenal gland, the factors regulating growth and differentiation of the fetal adrenal cortex have not been completely defined.

We recently presented evidence that activin-A inhibits human fetal adrenal cell proliferation and modulates the proliferative effects of epidermal growth factor (EGF) and TGF- $\beta$ (14). In the present study, we examined the expression of activin and inhibin subunits in the human fetal and adult adrenal gland. We also investigated the presence of dimeric activin- $A$ in fetal and neonatal adrenals. To provide insight into the regulation of these peptides in the adrenal cortex, we determined the effect of ACTH and a cAMP analogue on the accumulation of $\alpha$ and $\beta A$ subunit mRNAs by fetal adrenal cells and secretion of radioimmunoassayable $\alpha$-inhibin subunit by fetal and adult adrenal cell cultures. Finally, we present data on the differential effects of human recombinant activin and inhibin on human fetal and adult adrenal cell proliferation and steroidogenesis in vitro. Our studies indicate that activin and inhibin subunit expression is regulated by ACTH, and that recombinant human activin can enhance ACTH-stimulated steroidogenesis while inhibiting mitogenesis in human fetal adrenal cells. Unlike in other organ systems, these actions are not antagonized by inhibin, nor are they apparent in the adult human adrenal in vitro.

\section{Methods}

Primary culture of human fetal and adult adrenal cells. Human fetal adrenals were obtained immediately after laminaria-induced dilatation and evacuation. Fetuses ranged 14-24 wk gestational age, as judged by fetal foot length (15). Adult adrenal glands were obtained from organ 
donors (age 28-62 yr). Approval for the use of human material was given by the Human and Environmental Protection Committee, University of California, San Francisco (UCSF).

Fetal adrenal glands were decapsulated, and the inner surface of the capsule was scraped to remove the adherent definitive zone. Fetal and definitive zone tissues were then processed separately. For adult or fetal adrenal dispersions, tissue was minced and incubated for $30 \mathrm{~min}$ at $37^{\circ} \mathrm{C}$ in medium $\mathrm{M} 199$ containing $1 \mathrm{mg} / \mathrm{ml}$ collagenase-dispase (Boehringer Mannheim GmbH, Mannheim, FRG). Dispersed cells were filtered through a nylon mesh and centrifuged at $200 \mathrm{~g}$ for $8 \mathrm{~min}$. The pellet was resuspended in a culture medium consisting of a 1:1 ( vol/vol) mixture of M199 and Ham's F-12 with 10\% FCS, 2 mM glutamine, and $50 \mathrm{mg} / \mathrm{ml}$ gentamicin. (All media and additives were obtained from the Cell Culture Facility, UCSF). Cells were plated on 24 plastic multiwell plates (Falcon Plastics, Los Angeles, CA) at a density of $\sim 30,000$ cells / well, and were cultured at $37^{\circ} \mathrm{C}$ in a $95 \%$ air $/ 5 \%$ $\mathrm{CO}_{2}$ humidified environment. After $48 \mathrm{~h}$ incubation, medium was changed and test substances were added. Medium and test substances were renewed every $48 \mathrm{~h}$. Spent media were collected and stored at $-20^{\circ} \mathrm{C}$ for subsequent steroid or $\alpha$-inhibin RIA. Cell number in each well was determined after 2,4 , or $6 \mathrm{~d}$ incubation in the presence or absence of test substances after trypsinization, using a Coulter counter (Coulter Corp., Hialeah, FL).

Cell culture reagents. ACTH (adrenocorticotropin 1-24, Cortrosyn) was obtained from Organon Diagnostics, West Orange, NJ, and the cAMP analogue 8-bromoadenosine $3^{\prime}, 5^{\prime}$-cyclic monophosphate (8-Br-cAMP) was from Sigma Chemical Co., St. Louis, MO. EGF and basic fibroblast growth factor (FGF) were gifts of Dr. D. Gospodarowicz, UCSF. Recombinant human activin-A (rh-activin-A), recombinant human inhibin-A (rh-inhibin-A), and TGF- $\beta$ were generously provided by Dr. R. Schwall, Genentech Inc., South San Francisco, CA.

Test substances were added to cell dispersions on $\mathrm{d} 3$ of culture in the following concentrations: ACTH, $10 \mathrm{nM}$; EGF, $1.7 \mathrm{nM}$; FGF, 60 pM; rh-activin-A, 4 pM-40 nM; rh-inhibin-A, 4 pM-40 nM; and TGF$\beta, 400 \mathrm{pM}$. Duration of exposure to reagents varied from $1-4 \mathrm{~d}$, as specified in the text.

Subunit antibodies and monoclonal antibodies to activin- $A$. Antibodies to the $\alpha, \beta \mathrm{A}$, and $\beta \mathrm{B}$ subunits were the generous gift of $\mathrm{J}$. Vaughan and Dr. W. Vale, Peptide Biology Lab, The Salk Institute (La Jolla, CA). Each antiserum was produced in rabbits against synthetic inhibin fragments coupled to human $\alpha$-globulins. Preparation and characterization of the antisera have been described in detail previously (16-18).

Monoclonal antibodies specific for activin-A were the gift of Dr. Ralph Schwall, Genentech Inc. These antibodies were produced using the mutant hypogonadal (hpg) mouse (Jackson Laboratories, Bar Harbor, ME). Mice were hyperimmunized in the hind foot pad with 5- $\mu \mathrm{g}$ doses of purified recombinant activin-A. Inguinal and popliteal node lymphocytes were fused with a mouse myeloma cell line, as described previously (19). Production of antibodies by the resulting hybridomas was assessed by solid phase ELISA. Specificity was checked by a subsequent solid phase ELISA using inhibin-A as the coat antigen. Specificity was further characterized by testing for immunoprecipitation of metabolically labeled activin-A and inhibin-A, produced as described previously (20). The antibody used in the present studies did not crossreact with inhibin using either of these methods. Cross-reactivity of the monoclonal antibody to activin-A with activin subunits was tested by Western blot. $\beta \mathrm{A}$ monomer was generated by reducing intact, dimeric activin-A with $5 \% \beta$-mercaptoethanol at $55^{\circ} \mathrm{C}$ for $60 \mathrm{~min}$. Monoclonal antibody reacted with the intact activin-A dimer, showing a single band at $24 \mathrm{~K}$, but there was no detectable band in the lane containing the monomeric subunit. As a positive control, polyclonal antiserum made against activin-A showed bands with both the intact dimer and the monomeric subunit. Thus, no cross-reactivity was observed between the monoclonal antibody for activin-A and either inhibin-A or $\beta \mathrm{A}$ monomer.

Histology and immunocytochemistry. Human adult $(n=6)$ and midtrimester fetal $(n=8)$ adrenal glands, as well as a human anence- phalic adrenal gland specimen $(n=1)$, were fixed immediately at the time of necropsy in $4 \%$ paraformaldehyde and $0.15 \mathrm{M}$ phosphate buffer and kept for $24-72 \mathrm{~h}$ at $4^{\circ} \mathrm{C}$. The tissue was then dehydrated in alcohol and embedded in paraffin. Serial sections ( $8 \mu \mathrm{m}$ thick) were mounted on gelatin-alum-coated glass slides. Slides were deparaffinized in graded ethanols and hydrated to $0.1 \mathrm{M}$ Tris-buffered saline (TBS), pH 7.4, immediately before immunostaining.

Slides were pretreated with $0.01 \%$ sodium azide and $0.5 \% \mathrm{H}_{2} \mathrm{O}_{2}$ for $20 \mathrm{~min}$ and with $3 \%$ normal goat serum in TBS containing $1 \%$ BSA for $10 \mathrm{~min}$ at room temperature to block nonspecific staining. Slides for subunit immunostaining were incubated with subunit antibodies for $2 \mathrm{~h}$ at room temperature at the following dilutions: 1) 1:200 antiporcine inhibin- $\beta_{\mathrm{A}}$ cyclized Ac-(81-113)- $\left.\mathrm{NH}_{2} ; 2\right)$ 1:500 antiporcine inhibin- $\alpha$ (1-26)-Gly-Tyr; and 3) 1:300 anti-human inhibin- $\beta_{B}$ cyclized Ac-(80-112)- $\mathrm{NH}_{2}$. Slides for activin-A immunostaining were incubated for 2-6 $\mathrm{h}$ with a monoclonal antibody raised against the activin-A dimer at a concentration of $2-10 \mu \mathrm{g} / \mathrm{ml}$. Immunohistochemical staining was completed using the Vectastain Elite ABC Kit (Vector Laboratories, Inc., Burlingame, CA) with diaminobenzidine as the chromogen. Only faint uniform background was observed in control sections reacted either with absorbed antisera or with buffer in place of the primary antisera used. All sections were dehydrated in graded ethanols, cleared in xylene and mounted with Protexx (Scientific Products, McGraw Park, IL). Photographs were taken with Kodak Technical Pan film.

In situ hybridization. ${ }^{35} \mathrm{~S}$-labeled antisense mRNA probes specific for human inhibin $\alpha, \beta \mathrm{A}$, and $\beta \mathrm{B}$ were generated by transcription from the SP6 or T7 promoters of linearized pGEM4 subclones $(10,21)$. The human inhibin probe complementary to the $\alpha$ subunit comprised 1.3 $\mathrm{kb}$ of the full length $\alpha$ subunit. The human $\beta \mathrm{A}$ probe was $350 \mathrm{bp}$, including the final 73 amino acids at the $\mathrm{COOH}$-terminus and a portion of the $3^{\prime}$ untranslated region of the cDNA. The human $\beta \mathrm{B}$ probe was $1.8 \mathrm{~kb}$, corresponding to amino acid 42 to the $\mathrm{COOH}$-terminus and including approximately $800 \mathrm{bp}$ of the $3^{\prime}$ untranslated region. Background signal was determined using ${ }^{35} \mathrm{~S}$-labeled sense RNA probes for inhibin $\alpha, \beta \mathrm{A}$, and $\beta \mathrm{B}$.

Probes were applied at $55^{\circ} \mathrm{C}$ overnight in $50 \%$ formamide, $4 \times$ standard saline citrate (SSC), $1 \times$ Denhardt's solution, $100 \mu \mathrm{g} / \mathrm{ml}$ salmon sperm DNA, and $100 \mu \mathrm{g} / \mathrm{ml}$ yeast tRNA. Slides were washed in $2 \times$ SSC at room temperature for $15 \mathrm{~min}$ and then 4 times for $15 \mathrm{~min}$ in $0.5 \times \mathrm{SSC}$ at $55^{\circ} \mathrm{C}$. After RNAse treatment $(20 \mu \mathrm{g} / \mathrm{ml})$, slides were washed with $2 \times$ SSC, dipped in photographic emulsion (Kodak NTB2; Eastman Kodak Co., Rochester, NY), and exposed in light-tight boxes at $4^{\circ} \mathrm{C}$ for $7 \mathrm{~d}$. Slides were developed (Kodak D-19 developer), rinsed in tap water, and counterstained with cresyl violet.

To study the effects of ACTH on activin/inhibin subunit mRNA accumulation, fetal adrenal cells were cultured on eight-chamber glass microscope slides (Lab-Tek Div. Miles Laboratories Inc., Nunc, Naperville, IL) at a density of 10,000 cells/chamber. After $48 \mathrm{~h}$, the cells were stimulated for $24 \mathrm{~h}$ with either ACTH ( $10 \mathrm{nM}$ ) or 8-Br-cAMP ( 1 $\mathrm{mM})$. The cells were then fixed in $4 \%$ paraformaldehyde and subjected to in situ hybridization using ${ }^{35} \mathrm{~S}$-labeled $\alpha, \beta \mathrm{A}$, or $\beta \mathrm{B}$ subunit riboprobes, as described above.

RIA of the $\alpha$-inhibin chain. RIA of the inhibin- $\alpha$ subunit in culture medium was performed as previously described by Vaughan et al. (18), except that DSER ${ }^{1} \mathrm{Nle}^{5}$ human inhibin- $\alpha_{(1-25)}$ served as standard and was used as tracer following radiolabeling with ${ }^{125} \mathrm{I}$ and purification by HPLC. Inhibin levels are expressed in terms of highly purified $32 \mathrm{kD}$ ovine inhibin-A. The sensitivity of the RIA was $5.7 \pm 4.0 \mathrm{fmol} /$ tube.

Steroid RIA. DHAS was measured directly from conditioned medium as previously described (22). Cortisol was measured from etherextracted medium by RIA as described previously (23).

Statistical analysis. Experiments were repeated at least three times with samples in triplicate. Statistical comparisons between treatment groups were made by one-way analysis of variance (ANOVA) and Fisher protected least significant difference (PLSD) or Scheffe F-test as post tests. Results are expressed as mean \pm SEM. Significance was assumed at $P \leq 0.05$. 


\section{Results}

Immunohistochemical localization of activin and inhibin subunits in human fetal and adult adrenals. Immunohistochemical staining of midgestation fetal adrenals revealed the presence of $\alpha, \beta \mathrm{A}$, and $\beta \mathrm{B}$ subunits in scattered cells in both the fetal and definitive zones of the cortex. Distribution and staining intensity were similar for all three subunits; a representative example showing $\alpha$ subunit staining is shown in Fig. $1 A$. Medullary cells did not exhibit subunit immunostaining. An adrenal gland from an anencephalic 20-wk human fetus, which demonstrated the characteristic cortical atrophy of both fetal and definitive zones, was also subjected to immunohistochemical staining (Fig. $1 B$ ). This specimen showed markedly decreased subunit staining intensity relative to the normal midgestation adrenals.

In adult adrenal glands, immunoreactive $\alpha, \beta \mathrm{A}$, and $\beta \mathrm{B}$ subunits were noted primarily in scattered cells in the zonae glomerulosa and fasciculata. A representative section of adult adrenal immunostained with antibody to $\alpha$ subunit is shown in Fig. $1 D$. As in the fetal adrenal, no immunostaining was present in the medulla.

Immunoreactive activin-A dimer is present in fetal and neonatal adrenals. Using antibody specific for intact activin-A $(\beta \mathrm{A}-\beta \mathrm{A}$ dimer), immunostaining of midtrimester fetal and neonatal adrenal glands demonstrated the presence of activin$A$ in the outer cortex. An example of the activin-A staining pattern seen in a neonatal adrenal is depicted in Fig. $1 C$. The pattern of distribution was similar in fetus and neonate in that scattered positive cells occurred predominantly in the outer third of the cortex.

In situ hybridization of activin and inhibin subunit messenger $R N A s$. $\mathrm{mRNAs}$ for $\alpha, \beta \mathrm{A}$, and $\beta \mathrm{B}$ subunits were detected in fetal adrenal sections, in both the definitive and the fetal zones, and in cultured fetal zone cells ( $\beta$ A shown in Fig. 2). Treatment of dispersed fetal adrenal cells with ACTH ( $10 \mathrm{nM})$ or 8-Br-cAMP ( $1 \mathrm{mM}$ ) for $48 \mathrm{~h}$ enhanced the signal for $\alpha$ and $\beta \mathrm{A}$ mRNA, but not $\beta$ B ( $\alpha$ shown in Fig. 3).
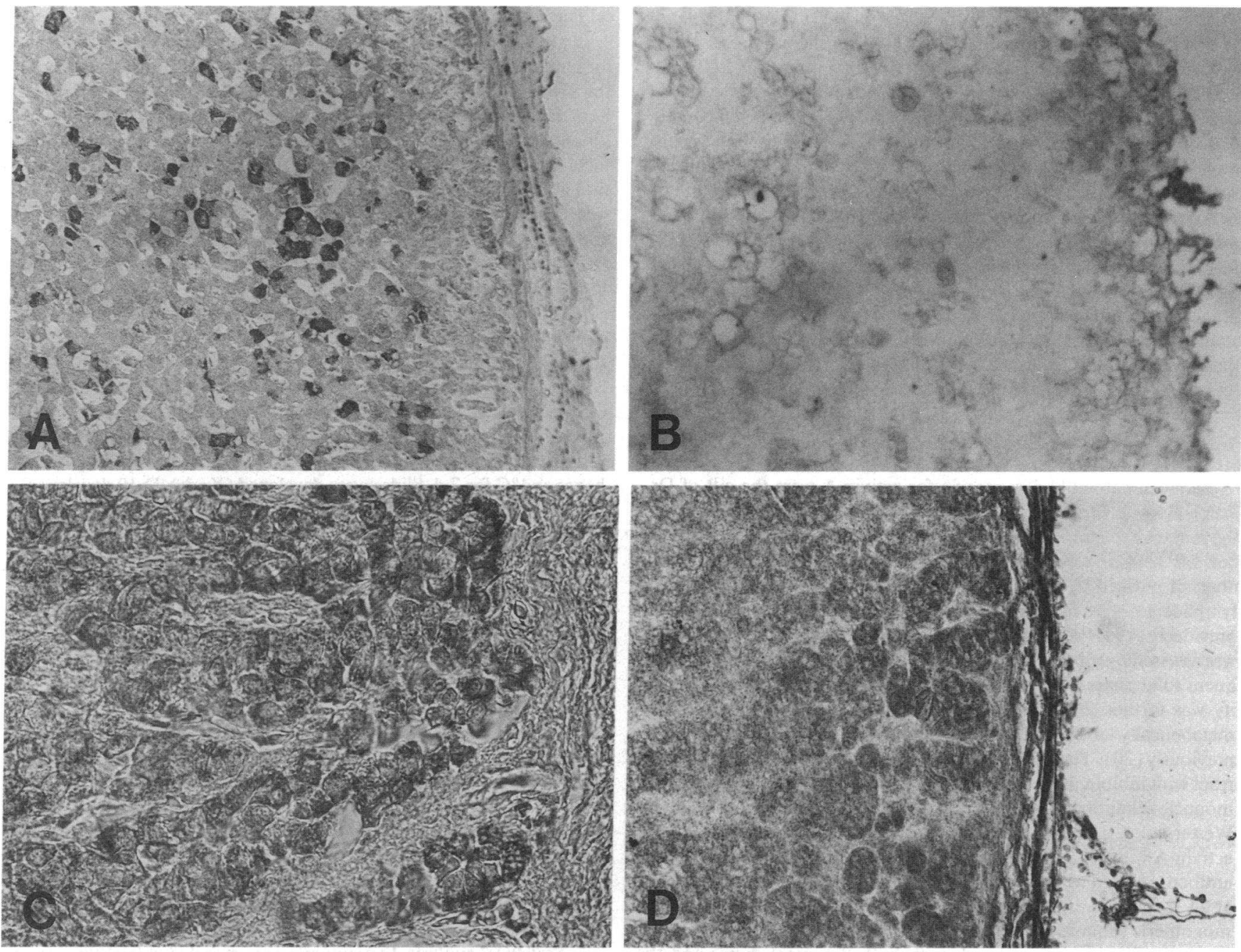

Figure 1. Immunohistochemical localization of $\alpha$-inhibin subunits and intact dimeric activin-A in the human adrenal. $(A)$ Fetal adrenal (midgestation ) immunostained for $\alpha$-inhibin subunit. Scattered intensely positive cells are present in the outer, definitive zone and inner, fetal zone of the cortex $(\times 150)$. (B) Anencephalic fetal adrenal (midgestation) immunostained for $\alpha$-inhibin subunit. Note diminished immunoreactivity in cortical cells $(\times 240)$. (C) Neonatal adrenal (one month postnatum) immunostained for intact activin-A $(\times 640)$. (D) Adult adrenal immunostained for $\alpha$-inhibin subunit $(\times 240)$. Positively staining cells are confined to zonae glomerulosa and fasciculata. 

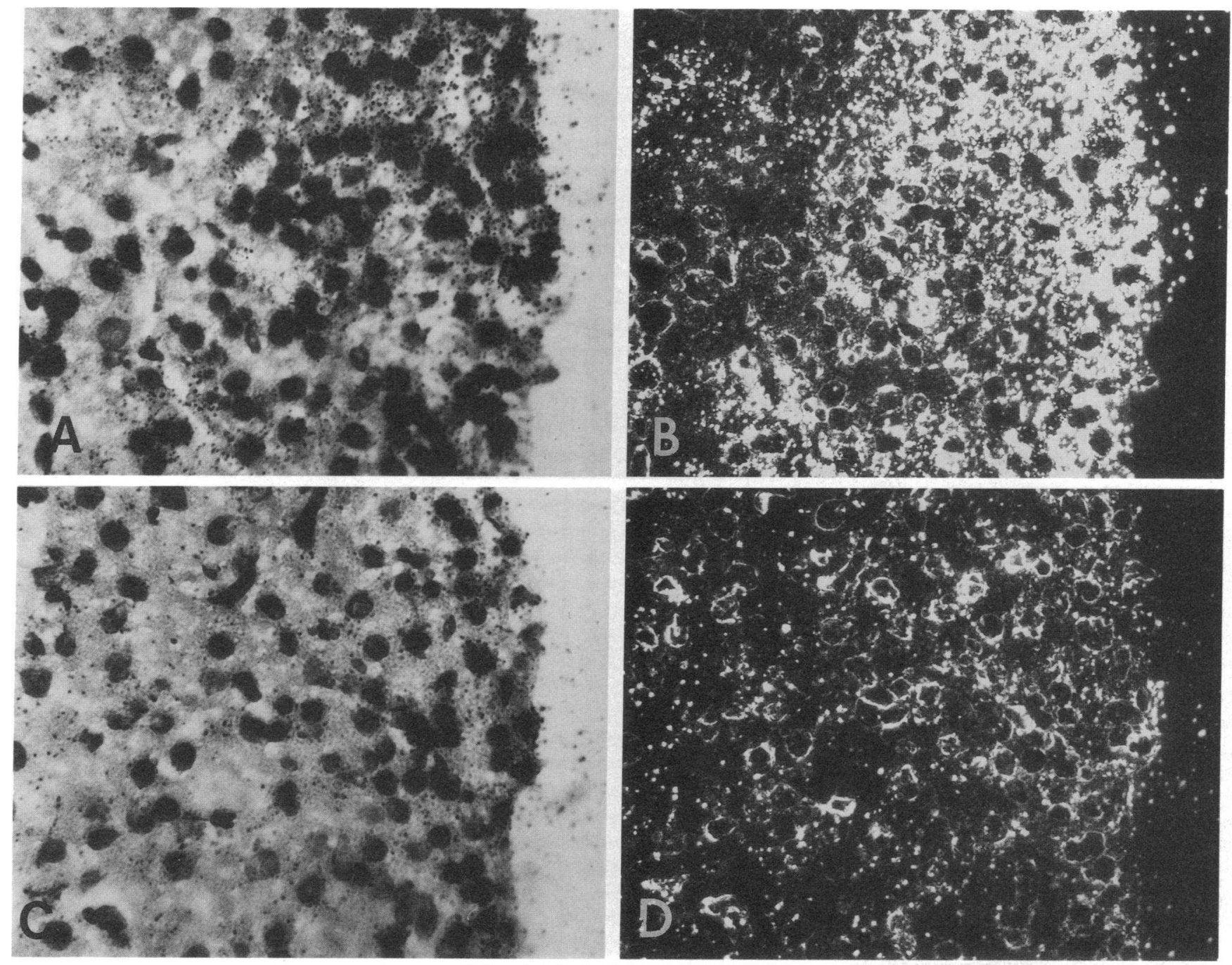

Figure 2. Localization of activin/inhibin $\beta$ A subunit mRNA by in situ hybridizations of ${ }^{35}$-labeled cRNA probe to cryostat tissue sections of midgestation human fetal adrenal. $(A)$ and $(C)$ are light field micrographs; $(B)$ and $(D)$ are the corresponding dark field micrographs. $(A, B)$ Outer, definitive zone and inner, fetal zone expression of $\beta$ A mRNA. $(C, D) \beta$ A subunit sense-strand (control). $(A-D, \times 600$.)

Secretion of $\alpha$ subunit by fetal and adult adrenal cells. Basal $\alpha$ inhibin secretion over $48 \mathrm{~h}$ by cultured fetal zone cells was assayable near the detection limit of the assay $(44 \mathrm{fmol} / \mathrm{ml})$ whereas basal definitive zone $\alpha$ subunit secretion was present at slightly higher levels (mean: $234 \pm 20 \mathrm{fmol} / \mathrm{ml}$ per 100,000 cells). Addition of ACTH $\left(10^{-6}\right.$ to $\left.10^{-10} \mathrm{M}\right)$ to the culture medium of both fetal and definitive zone cells for $48 \mathrm{~h}$ before harvesting yielded a dose-dependent increase in the levels of secreted $\alpha$ subunit (Fig. 4). Addition of $1 \mathrm{mM}$ 8-Br-cAMP similarly increased $\alpha$ subunit secretion (Fig. 4). Fresh culture medium (M199/Ham's F-12 medium with $10 \%$ FCS) contained no detectable $\alpha$ chain by RIA.

Adult adrenal cells under basal conditions secreted low but detectable levels of $\alpha$ inhibin $(52 \pm 13 \mathrm{fmol} / \mathrm{ml}$ per 100,000 cells). Addition of $10 \mathrm{nM}$ ACTH to adult cell dispersions for 48 $h$ before harvesting caused a fivefold increase in secreted radioimmunoassayable $\alpha$-inhibin (Fig. 4).

The peptide growth factors EGF, FGF, and TGF- $\beta$ also were tested for their ability to stimulate $\alpha$-inhibin secretion. At doses known to inhibit (TGF- $\beta)(14,24)$ or stimulate (EGF,
FGF) $(25,26)$ fetal adrenal cell proliferation, these growth factors had no statistically significant effect on $\alpha$ subunit secretion relative to control (data not shown). Similarly, treatment of the cultures with rh-activin-A ( $4 \mathrm{pM}-40 \mathrm{nM})$ did not alter secretion of $\alpha$ subunit.

Activin-A selectively inhibits fetal zone proliferation. We previously reported that rh-activin-A inhibits proliferation of human fetal zone adrenal cells in a dose- and time-dependent fashion, starting at $48 \mathrm{~h}$ and reaching maximal inhibition to $50 \%$ of control by d 6 of culture (14). We have extended our observations to compare the effects of activin and inhibin on fetal zone, definitive zone, and adult adrenal cell proliferation. In contrast to its effect on fetal zone cells, rh-activin-A (4 pM$40 \mathrm{nM}$ ) did not alter growth of definitive zone or adult adrenal cells. Fig. $5 \mathrm{~A}$ demonstrates the decrease in fetal zone cell number after 1-4 d exposure to activin-A (d 3-6 of culture). Activin-A had no significant effect on definitive zone (Fig. $5 B$ ) or adult (Fig. $5 C$ ) cell number over the same time period. Rh-inhibin-A ( $4 \mathrm{pM}-40 \mathrm{nM}$ ) had no mitogenic effects on cell number in fetal zone, definitive zone, or adult adrenal cultures 

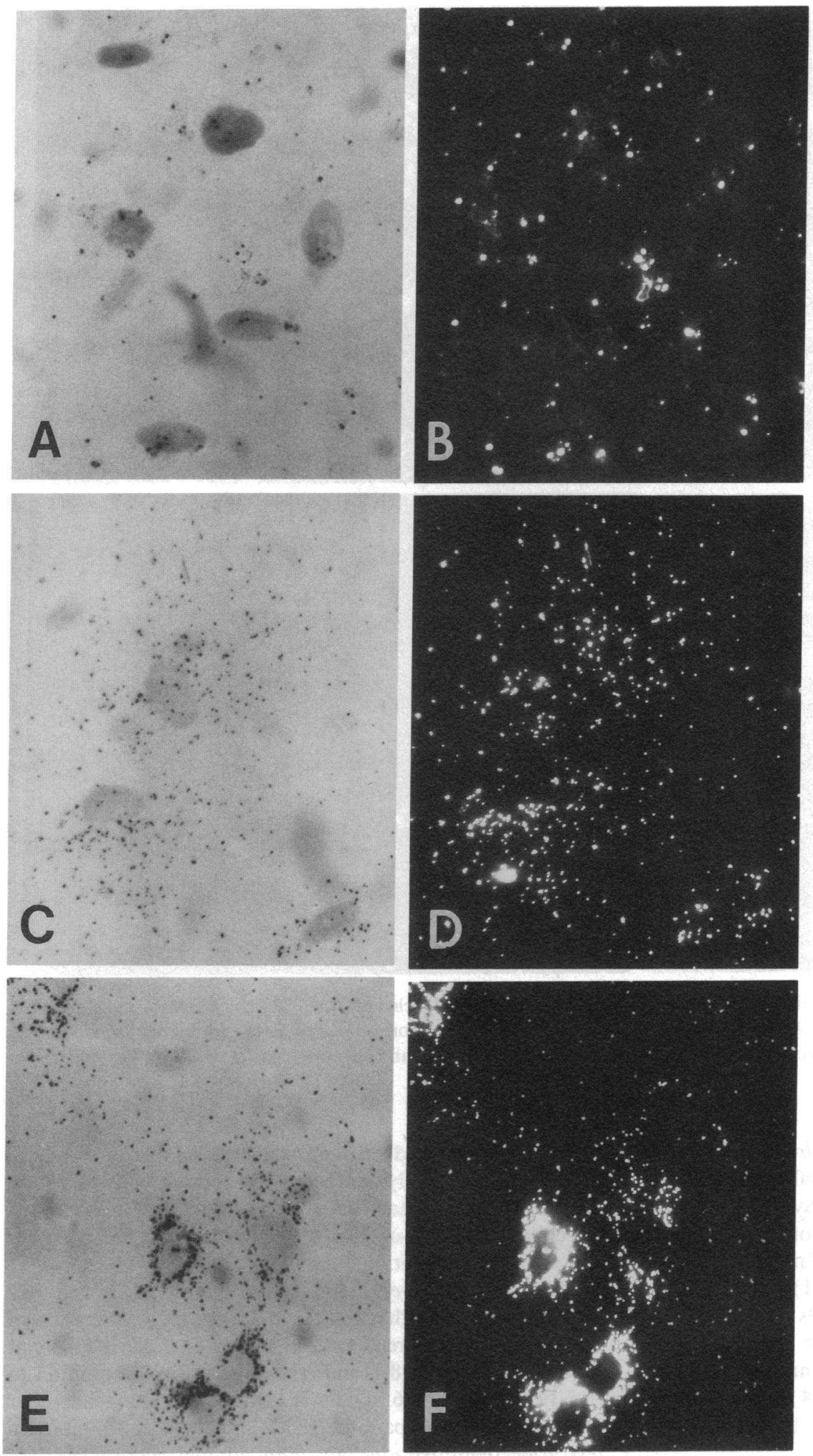

Figure 3. In situ hybridization of $\alpha$ subunit RNA in cultured midgestation fetal adrenal cells. $(A)$, $(C)$, and $(E)$ are light field micrographs; $(B)$, $(D)$, and $(F)$ are the corresponding dark field micrographs. $(A, B)$ Control (sense strand RNA) hybridization. $(C, D)$ Basal expression of $\alpha$ mRNA. $(E, F) \alpha$ subunit expression after incubation with ACTH ( $10 \mathrm{nM}$ ) for $48 \mathrm{~h}$, demonstrating increased accumulation of $\alpha$ mRNA. [( $A-F), \times 600$.

(data not shown). Similarly, inhibin in the same dose range did not affect stimulation of proliferation by EGF or FGF, or inhibition of proliferation by rh-activin-A or TGF- $\beta$.

Activin-A enhances ACTH-stimulated cortisol production by fetal zone cells. Rh-activin-A in doses $\geq 10 \mathrm{ng} / \mathrm{ml}(400 \mathrm{pM})$ significantly increased ACTH-stimulated secretion of cortisol by fetal zone cells $(474.6 \pm 92.3 \mathrm{ng} / 100,000$ cells per $24 \mathrm{~h}$ with $10 \mathrm{nM}$ ACTH vs. $864.8 \pm 127.3 \mathrm{ng} / 100,000$ cells per $24 \mathrm{~h}$ with $10 \mathrm{nM}$ ACTH and $4 \mathrm{nM}$ rh-activin-A) (Fig. 6). Rh-activin-A did not significantly alter basal cortisol production by definitive or fetal zone cells, or basal DHAS production by fetal zone cells in primary culture. In contrast to activin, rh-inhibin-A 

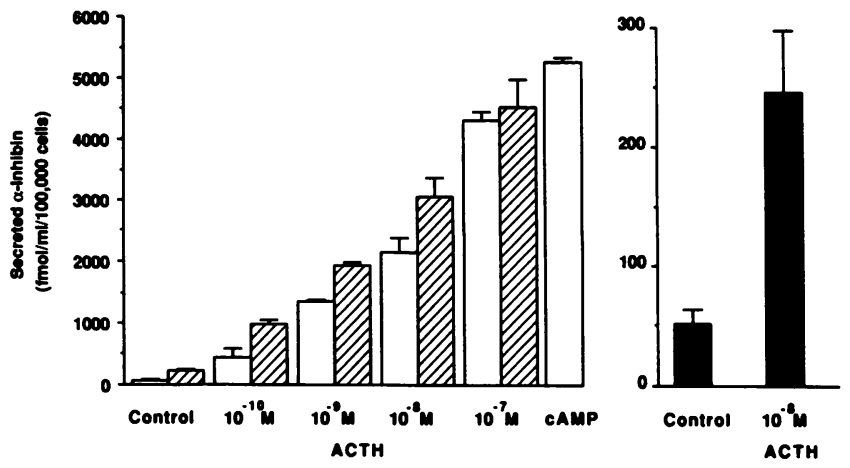

Figure 4. Secretion of $\alpha$-inhibin subunit by adrenal cell cultures. Radioimmunoassayable $\alpha$-inhibin subunit, expressed in $\mathrm{fmol} / \mathrm{ml}$ per $10^{5}$ cells per $48 \mathrm{~h}$, in fetal zone (white bars), definitive zone ( $h a t c h e d$ bars), and adult (black bars) adrenal cell conditioned culture medium, in the presence of ACTH or 8-Br-cAMP, as indicated. Please note the different scales of the two graphs. Data are presented as means of triplicate values \pm SEM.
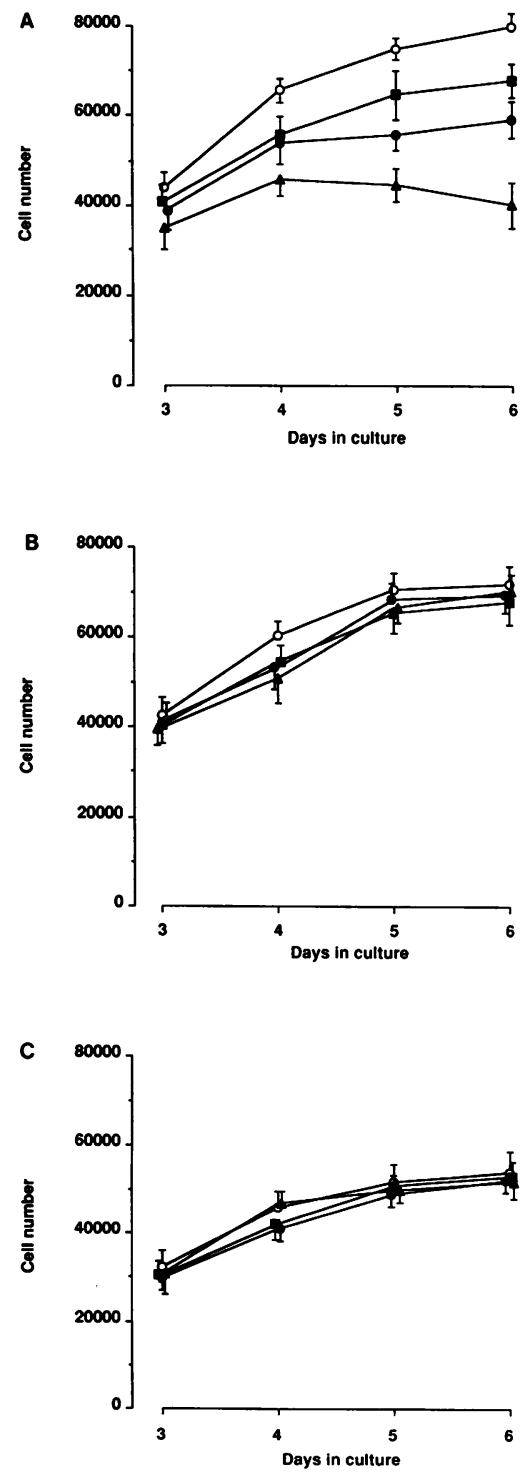

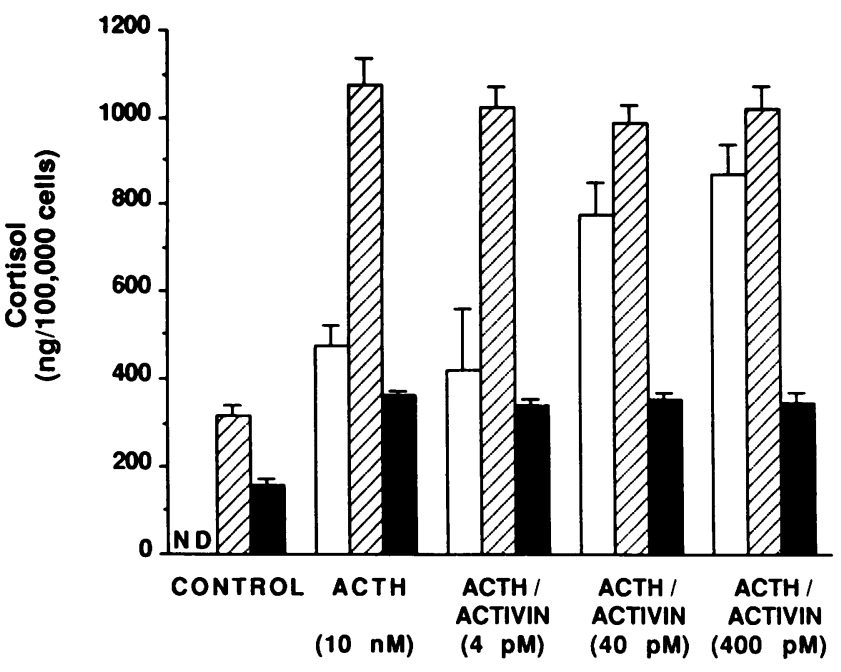

Figure 6. Effect of human recombinant activin-A on ACTH-stimulated cortisol production by cultured fetal and adult adrenal cells. Cortisol values are expressed as $\mathrm{ng} / \mathrm{ml}$ per $10^{5}$ cells per $48 \mathrm{~h}$ in conditioned medium from fetal zone (white bars), definitive zone ( hatched bars), or adult (black bars) adrenal cell cultures. The data are means \pm SE of triplicate experiments.

had no effect on basal or ACTH-stimulated fetal adrenal steroidogenesis (cortisol or DHAS secretion ). In human adult adrenal cell dispersions, neither activin nor inhibin, alone or in combination, affected basal or ACTH-stimulated cortisol secretion (Fig. 6). However, these adult cultures were capable of responding to ACTH ( $10 \mathrm{nM})$ with a twofold increase in secreted cortisol.

\section{Discussion}

Evidence is accumulating for a pivotal role for activins and inhibins during development. Recent work has demonstrated mesodermal induction by activin in Xenopus embryos (3). Activin and inhibin subunit mRNAs are widely expressed in the developing rat embryo in endocrine and nonendocrine tissues (gonads, brain, and integumentary derivatives) (27). The human placenta also expresses activin and inhibin subunit mRNAs, and in vitro, activin increased gonadotropin-releasing hormone ( $\mathrm{GnRH}$ ) and progesterone production, and it potentiated the GnRH-induced release of chorionic gonadotropin from cultured placental cells (28). Thus, activins and inhibins have been implicated in the endocrine physiology of pregnancy.

The data presented here indicate that activin and inhibin subunit proteins and their mRNAs are expressed in the midtrimester human fetal adrenal gland, and that the subunit proteins also are present in the adult adrenal gland. In the adrenal gland from an anencephalic fetus (which was deficient in pituitary ACTH), subunit immunostaining was markedly diminished. ACTH stimulated accumulation of $\alpha$ and $\beta$ A mRNA by fetal adrenal cells and secretion of $\alpha$-inhibin subunit by cultured fetal and adult adrenal cells. Although activin modulated ACTH-induced cortisol synthesis in fetal zone cells, neither rh-activin-A nor rh-inhibin-A altered mitogenesis or cortisol production in dispersed adult cells. The physiological role of 
these peptides in the adult adrenal, if any, remains to be elucidated. The actions of activin-A on fetal but not adult adrenal cell growth and steroidogenesis suggest a developmental role for this peptide in the immature human adrenal gland.

Postnatally, the fetal zone undergoes involution and/or remodeling. The adult zonae glomerulosa, fasciculata, and reticularis are formed from the definitive cortex with an undefined contribution from maturational changes in the fetal zone (29). A primate fetal zone transformation to form part of the adult cortex has been proposed previously $(30,31)$. The ACTH-induced shift from primarily DHAS production to increased cortisol production in the fetal zone is analogous to the shift in steroidogenesis that occurs postnatally. Activin enhanced this ACTH-induced shift and at the same time inhibited proliferation of fetal zone cells. It is tempting to speculate that activin's combined actions in decreasing cell growth while enhancing steroidogenesis could permit a shift in cellular metabolism from proliferation to differentiated function, such as that which may occur in the remodeling of the fetal zone postnatally.

In the present study, ACTH was shown to enhance the expression of both $\alpha$ and $\beta$ A subunit mRNA and protein, and to stimulate the secretion of the $\alpha$ inhibin subunit by dispersed human fetal and adult adrenal cells. This is consistent with the presence of a potential cAMP-responsive element identified in the $\alpha$ subunit gene (32) and extends the observation by Crawford et al. that ACTH administration increases the level of $\alpha$-inhibin mRNA in the adult ewe (11). Treatment of fetal adrenal cultures with activin-A or its structural homologue, TGF- $\beta$, did not stimulate secretion of the $\alpha$-inhibin subunit, in contrast to previous data from cultured rat granulosa cells (33). This difference may reflect species-specific, organ-specific, and/or developmentally dependent regulation of subunit production.

Using immunohistochemistry with an antibody to dimeric activin, we have demonstrated the presence of activin-A dimer in the fetal and neonatal adrenal. However, it is not possible to make definitive conclusions regarding synthesis of intact inhibin by the fetal adrenal, as the immunohistochemical signal for $\alpha$-inhibin may represent isolated $\alpha$ subunit production. In addition, it is known that the RIA utilized to assess $\alpha$ subunit secretion also recognizes monomeric $\alpha$ subunit and the posttranslationally processed subunit, Pro- $\alpha_{c}(34)$. None of these products of pro- $\alpha$ subunit posttranslational processing has inhibin bioactivity (i.e., FSH-suppressing activity) in the in vitro rat pituitary cell bioassay $(35,36)$. Nevertheless, given in situ production of both $\alpha$ and $\beta$ subunits, the human fetal adrenal gland does have the potential for synthesis of the intact inhibin dimer. Use of antibody probes to the intact inhibin dimer, when available, should clarify this issue.

$\mathrm{Rh}$-inhibin-A had no apparent mitogenic action or effect on cortisol or DHAS production in our adrenal culture system. The rh-inhibin-A used in our experiments was biologically active in a pituitary dispersion bioassay (i.e., inhibition of GnRH-stimulated FSH release) (4). To date, we have not identified a role for inhibin in fetal adrenal function. From other studies, including in vitro assays of testicular and ovarian steroidogenesis, it appears that inhibin alone is not active, but rather may serve as a modulator of the effects of trophic hormones (FSH and luteinizing hormone) and activin $(37,38)$. Although a modulatory role for inhibin on the effects of activin was not observed in this study, we cannot exclude such interaction in the human fetal adrenal in vivo.

In summary, we have demonstrated that activin-A is expressed in steroidogenic adrenocortical cells in the human fetal adrenal gland, is regulated by ACTH and CAMP, and can inhibit mitogenesis while enhancing ACTH-stimulated cortisol synthesis, a marker of differentiated function in fetal zone cells. Thus, activin-A may be an autocrine or paracrine factor involved in modulating growth and differentiated function in the human fetal adrenal gland.

\section{Acknowledgments}

We thank Dr. R. Schwall for providing recombinant activin and inhibin, intact activin probe, and TGF- $\beta$; J. Vaughan and Dr. W. Vale for subunit antibodies and the $\alpha$-inhibin radioimmunoassay; Dr. $\mathrm{H}$. Meunier for subunit plasmids; and C. Padula for expert technical assistance.

This work was supported in part by National Institute of Child Health and Human Development grants HD-08478 and P30 Center Grant 11729, National Institutes of Health training grant HD-0746601 to Susan J. Spencer, and Fogarty Fellowship TW04258-01 to Jaron Rabinovici.

\section{References}

1. Roberts, A. B., K. C. Flanders, P. Kondaiah, N. L. Thompson, E. van Obberghen-Schilling, L. M. Wakefield, P. Rossi, B. de Crombrugghe, U. Heine, and M. B. Sporn. 1990. Transforming growth factor beta: biochemistry and roles in embryogenesis, tissue repair and remodeling and carcinogenesis. Recent Prog. Horm. Res. 44:157-197.

2. Ying, S. Y. 1988. Inhibins, activins, and follistatins: gonadal proteins modulating the secretion of follicle-stimulating hormone. Endocr. Rev. 9:267-293.

3. Thomsen, G., T. Woolf, M. Whitman, S. Sokol, J. Vaughan, W. Vale, and D. A. Melton. 1990. Activins are expressed early in Xenopus embryogenesis and can induce axial mesoderm and anterior structures. Cell. 63:485-493.

4. Broxmeyer, H., L. Lu, S. Cooper, R. Schwall, A. Mason, and K. Nikolics. 1988. Selective and indirect modulation of human multipotential and erythroid hematopoietic progenitor cell proliferation by recombinant human activin and inhibin. Proc. Natl. Acad. Sci. USA. 85:9052-9056.

5. Schwall, R., C. H. Schmelzer, E. Matzuyama, and A. J. Mason. 1989. Multiple actions of recombinant activin-A in vivo. Endocrinology. 125:14201423.

6. Yu, J., L. E. Shao, V. Lemas, A. L. Yu, J. Vaughan, J. Rivier, and W. Vale. 1987. Importance of FSH-releasing protein and inhibin in erythrodifferentiation. Nature (Lond.). 330:765-767.

7. Bilezikjian, L. M., A. Z. Corrigan, and W. Vale. 1990. Activin-A modulates growth hormone secretion from cultures of rat anterior pituitary cells. Endocrinology. 126:2369-2376.

8. Ling, N., S. Y. Ying, N. Ueno, S. Shimasaki, F. Esch, M. Hotta, and R. Guillemin. 1986. A homodimer of the beta-subunits of inhibin A stimulates the secretion of pituitary follicle stimulating hormone. Biochem. Biophys. Res. Commun. 138:1129-1137.

9. McLachlan, R. I., D. M. Robertson, D. DeKretser, and H. G. Burger. 1987. Inhibin-a non-steroidal regulator of pituitary follicle stimulating hormone. Bailliere's Clin. Endocrinol. Metab. 1:89-112.

10. Meunier, H., C. Rivier, R. M. Evans, and W. Vale. 1988. Gonadal and extragonadal expression of inhibin alpha, beta $A$, and beta $B$ subunits in various tissues predicts diverse functions. Proc. Natl. Acad. Sci. USA. 85:247-251.

11. Crawford, R. J., V. E. Hammond, B. A. Evans, J. P. Coghlan, J. Haralambidis, B. Hudson, J. D. Penschow, R. I. Richards, and G. W. Tregear. 1987. $\alpha$-Inhibin gene expression occurs in the ovine adrenal cortex, and is regulated by adrenocorticotropin. Mol. Endocrinol. 1:699-706.

12. Serón-Ferré, M., C. Lawrence, P. Siiteri, and R. Jaffe. 1978. Steroid production by the definitive and fetal zones of the human fetal adrenal gland. J. Clin. Endocrinol. \& Metab. 47:603-609.

13. Siiteri, P. K., and P. C. MacDonald. 1963. The utilization of circulating dehydroisoandrosterone sulfate for estrogen synthesis during human pregnancy. Steroids. 2:713-730.

14. Spencer, S. J., J. Rabinovici, and R. B. Jaffe. 1990. Human recombinant activin-A inhibits proliferation of human fetal adrenal cells in vitro. J. Clin Endocrinol. \& Metab. 71:1678-1680. 
15. Munsick, R. 1984. Human fetal extremity lengths in the interval from 9 to 21 menstrual weeks of pregnancy. Am. J. Obstet. Gynecol. 149:883-887.

16. Roberts, V., H. Meunier, P. E. Sawchenko, and W. Vale. 1989. Differential production and regulation of inhibin subunits in rat testicular cell types. Endocrinology. 125:2350-2359.

17. Roberts, V., H. Meunier, J. Vaughan, J. Rivier, C. Rivier, W. Vale, and P. Sawchenko. 1989. Production and regulation of inhibin subunits in pituitary gonadotropes. Endocrinology. 124:552-554.

18. Vaughan, J. M., J. Rivier, A. Z. Corrigan, R. McClintock, C. A. Campen, D. Jolley, J. K. Voglmayr, C. W. Bardin, C. Rivier, and W. Vale. 1989. Detection and purification of inhibin using antisera generated against synthetic peptide fragments. In Methods in Enzymology. P. M. Conn and P. S. Conn, editors. Academic Press, Inc. Orlando, FL. 588-617.

19. Lucas, C., L. N. Bold, B. M. Fendly, M. Mora-Wormd, I. S. Figari, E. J. Patzer, and M. A. Palladino. 1990. The autocrine production of transforming growth factor- $\beta 1$ during lymphocyte activation: a study with a monoclonal antibody-based ELISA. J. Immunol. 145:1415-1422.

20. Schwall, R. H., K. Nikolics, E. Szonyi, C. Gorman, and A. J. Mason. 1988. Recombinant expression and characterization of human activin A. Mol. Endocrinol. 2:1237-1242.

21. Meunier, H., S. B. Cajander, V. J. Roberts, C. Rivier, P. E. Sawchenko, A. J. Hsueh, and W. Vale. 1988. Rapid changes in the expression of inhibin alpha-, beta A-, and beta B-subunits in ovarian cell types during the rat estrous cycle. Mol. Endocrinol. 2:1352-1363.

22. Koritnik, D., D. Rotten, R. Laherty, and R. Jaffe. 1983. A radioimmunoassay for dehydroepiandrosterone sulfate in the circulation of Rhesus monkeys. Steroids. 42:653-667.

23. Mitchell, B., M. Serón-Ferré, and R. Jaffe. 1982. Cortisol-cortisone interrelationships in the late gestation rhesus monkey fetus in utero. Endocrinology. 111:1837-1847.

24. Riopal, L., C. Branchaud, C. Goodyer, V. Adkar, and Y. Lefebvre. 1989 Growth-inhibitory effect of TGF-beta on human fetal adrenal cells in primary monolayer culture. J. Cell Physiol. 140:233-238.

25. Crickard, K., C. Ill, and R. B. Jaffe. 1981. Control of proliferation of human fetal adrenal cells in vitro. J. Clin. Endocrinol. \& Metab. 53:790-796.

26. Mesiano, S., S. H. Mellon, D. Gospodarowicz, A. M. DiBlasio, and R. B. Jaffe. 1991. Basic fibroblast growth factor expression is regulated by corticotropin in the human fetal adrenal: a model for adrenal growth regulation. Proc. Natl. Acad. Sci., USA. 88:5428-5432.

27. Roberts, V. J., P. E. Sawchenko, and W. W. Vale. 1990. Distribution of inhibin/activin subunit mRNAs in developing rat embryos. Endocrine Society, 72nd Annual Meeting. Atlanta, Georgia. (Abstr.)

28. Petraglia, F., J. Vaughn, and W. Vale. 1988. Inhibin and activin modulate the release of gonadotropin-releasing hormone, human chorionic gonadotropin, and progesterone from cultured human placental cells. Proc. Natl. Acad. Sci. USA. 86:5114-5117.

29. Sucheston, M. E., and M. S. Cannon. 1968. Development of zonular patterns in the human adrenal gland. J. Morphol. 126:477-492.

30. McNulty, W. P. 1981. Postnatum evolution of the adrenal glands of rhesus macaques. In Fetal Endocrinology. M. Novy and R. Resko, editors. Academic Press Inc., New York. 53-64.

31. McNulty, W. P., M. J. Novy, and S. W. Walsh. 1981. Fetal and postnatal development of the adrenal glands in Macaca mulatta. Biol. Reprod. 25:10791089.

32. Feng, Z. M., Y. P. Li, and C. L. Chen. 1989. Analysis of the 5 '-flanking regions of rat inhibin alpha- and beta-B-subunit genes suggest two different regulatory mechanisms. Mol. Endocrinol. 3:1914-1925.

33. LaPolt, P. S., D. Soto, J.-G. Su, C. A. Campen, J. Vaughan, W. Vale, and A. J. Hsueh. 1989. Activin stimulation of inhibin secretion and messenger RNA levels in cultured granulosa cells. Mol. Endocrinol. 3:1666-1673.

34. Schneyer, A. L., A. J. Mason, L. E. Burton, J. R. Ziegner, and W. J. Crowley. 1990. Immunoreactive inhibin alpha-subunit in human serum: implications for radioimmunoassay. J. Clin. Endocrinol. \& Metab. 70:1208-1212.

35. Robertson, D. M., M. Giacometti, L. M. Foulds, J. Lahnstein, N. H. Goss, M. T. W. Hearn, and D. M. de Kretzer. 1989. Isolation of inhibin a-subunit precursor proteins from bovine follicular fluid. Endocrinology. 125:2141-2149.

36. Sugino, K., T. Nakamura, Y. Hasegawa, K. Miyamoto, M. Igarashi, Y. Eto, H. Shibai, and K. Titani. 1989. Inhibin alpha subunit monomer is present in bovine follicular fluid. Biochem. Biophys. Res. Commun. 159:1323-1329.

37. Findlay, J. K., X. Sai, and L. Shukovski. 1990. Role of inhibin-related peptides as intragonadal regulators. Reprod. Fertil. Dev. 2:205-218.

38. Hsueh, A. J., K. D. Dahl, J. Vaughan, E. Tucker, J. Rivier, C. W. Bardin, and W. Vale. 1987. Heterodimers and homodimers of inhibin subunits have different paracrine action in the modulation of luteinizing hormone-stimulated androgen biosynthesis. Proc. Natl. Acad. Sci. USA. 84:5082-5086. 